Gut, 1971, 12, 237-244

\title{
Peritoneoscopic features of intraabdominal vessels in cirrhosis of the liver
}

\author{
G. P. JORI AND G. MAZZACCA \\ From the Institute of Medical Pathology, University of Naples, Italy
}

SUMMARY Peritoneoscopy was carried out in 57 cirrhotic patients in order to evaluate the morphological features of intraabdominal veins. These were described either as normal or characterized by minimal, moderate, or marked alterations: accordingly, the patients were classified into four groups. Intrahepatic and intrasplenic pressures were measured in most patients; abnormally elevated values were found in every case, and the higher figures belonged to the subjects with minor involvement of the intraabdominal veins. Superficial collateralization and oesophageal varices appeared unrelated to changes in these veins, whereas splenomegaly was mostly found in patients with normal or slightly altered intraabdominal veins. Percutaneous splenoportography was performed in 16 patients, and venographic appearances did not correlate with peritoneoscopic features of the intraabdominal veins. Ascites, on the other hand, was exclusively present in patients with alterations in these veins. It is suggested that some pathogenetic relationship might exist between changes in intraabdominal veins seen by peritoneoscopy and ascites.

In experienced hands peritoneoscopy is a simple and safe procedure whose usefulness in the differential diagnosis of liver disease has been emphasized by many authors (Siede and Schneider, 1962; Palmer and Boyce, 1964; Wittman, 1966; Beck, Dischler, Helms, Kiani, Sickinger, and Tenner, 1968). Its value in assessing the portal collateral circulation, however, has so far been underestimated. In a recent review (Williams, 1967) peritoneoscopy is not included among the presently available methods for investigating patients with portal hypertension.

Representative areas of the intraabdominal veins, indeed, are well within the peritoneoscopic visual field. These include omental and peritoneal vessels, gastric veins, and intestinal venous radicles. Moreover, peritoneoscopy often discloses the development of collateral channels.

This paper considers certain morphological features of the intraabdominal veins in cirrhotic patients, as evaluated by peritoneoscopy. The relationship of these endoscopic views with other findings attributable to portal hypertension will be discussed.

\section{Materials and Methods}

The study comprises 57 patients with portal or Received for publication 6 January 1971. postnecrotic cirrhosis, 37 males and 20 females aged between 14 and 74, in all of whom the diagnosis had been confirmed by histological examination of liver biopsies. All the subjects were inpatients in our hospital.

Among the procedures which were carried out in the patients, the following are pertinent to the aims of this report (if not otherwise indicated, they are to be considered as performed in every patient).

\section{PERITONEOSCOPY}

It was performed with the Menghini photoperitoneoscope, manufactured by Karl Storz, West Germany; colour films were taken on Ektachrome highspeed 23 DIN, by exposure to electronic flash for $1 / 30$ of a second.

\section{HEPATIC BIOPSY}

This was performed under direct visual control, using either the Menghini or Vim-Silverman needles. The latter were used when intrahepatic pressure measurements were taken.

3 INTRAHEPATIC PRESSURE MEASUREMENT This was done in 21 patients, as described by OrregoMatte, Amenabar, Lara, Baraona, Palma, and Massad (1964). 
4 INTRASPLENIC PRESSURE MEASUREMENT This was done in 22 patients, as described by Atkinson and Sherlock (1954).

\section{BARIUM SWALLOW}

The oesophagus was examined using a barium swallow for assessing the presence of oesophageal varices.

\section{SPLENOPORTOGRAPHY}

Splenoportography was done in 16 patients, as described by Steiner, Sherlock, and Turner (1957).

Abdominal wall collateralization was evaluated on closer inspection by more than one observer. Doubtful cases were studied by infra-red photography, using Kodak IR-135 films. The splenic size was carefully evaluated by physical examination, and afterwards reassessed by peritoneoscopic inspection. In every patient the presence of ascites was initially sought by physical examination, and subsequently reassessed by peritoneoscopy. Furthermore, the patients were carefully interrogated about any previous weight gain, abdominal swelling, paracentesis, oliguria, and the use of diuretic drugs. Most often, additional information was obtained from private physicians and from the patients' families.

\section{Results}

The results afforded by the present investigation are summarized in Tables I-IV. The patients were grouped according to the peritoneoscopic appearances of the intraabdominal veins. The criteria adopted for such a classification have already been described (Beck et al, 1968; Solmi and Righi Riva, 1968). Three patients were eliminated from the study because of borderline features between one group and another.

\section{GROUP 1}

Twenty-five patients $(43.8 \%)$ proved to have normal intraabdominal veins, even at the closest peritoneoscopic examination (Table I and Figs. 1 and 2).

\section{GROUP 2}

Intraabdominal venous changes, although present, were classified as minimal in 16 patients $(28 \%)$, whose vascular engorgement was limited to the

\begin{tabular}{|c|c|c|c|c|c|c|c|c|}
\hline Patient & $\begin{array}{l}\text { Age } \\
\text { (yr) }\end{array}$ & Sex & Splenomegaly 1 & $\begin{array}{l}\text { Oesophageal } \\
\text { Varices }\end{array}$ & $\begin{array}{l}\text { Superficial } \\
\text { Abdominal } \\
\text { Collateralization }\end{array}$ & Ascites & $\begin{array}{l}\text { Intrahepatic } \\
\text { Pressures } \\
\text { (mm Hg) }\end{array}$ & $\begin{array}{l}\text { Intrasplenic } \\
\text { Pressures } \\
\text { ( } \mathrm{mm} \mathrm{Hg})\end{array}$ \\
\hline
\end{tabular}

Table I Peritoneoscopy picture in group 1 patients with normal intraabdominal veins

${ }^{1}$ Splenic size was determined by physical examination and in every patient reassessed at the time of peritoneoscopy. Findings were graded as follows:

- = normal

$+=$ inferior pole $1-2$ fingerbreadths below costal margin

$++=$ inferior pole to umbilical transverse line

$+++=$ inferior pole below umbilical transverse line

2n.d. = not determined 


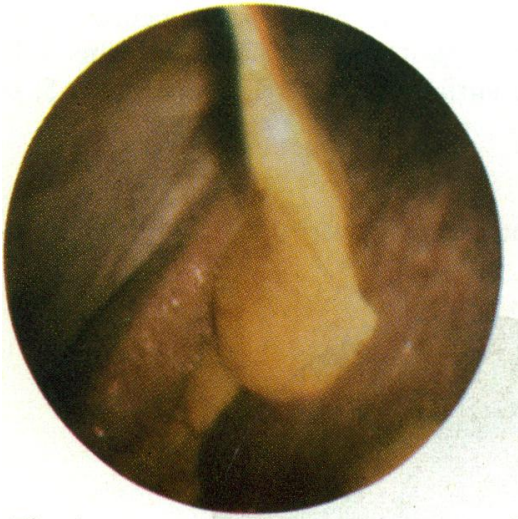

Fig. 1.

\section{Fig. 2.}
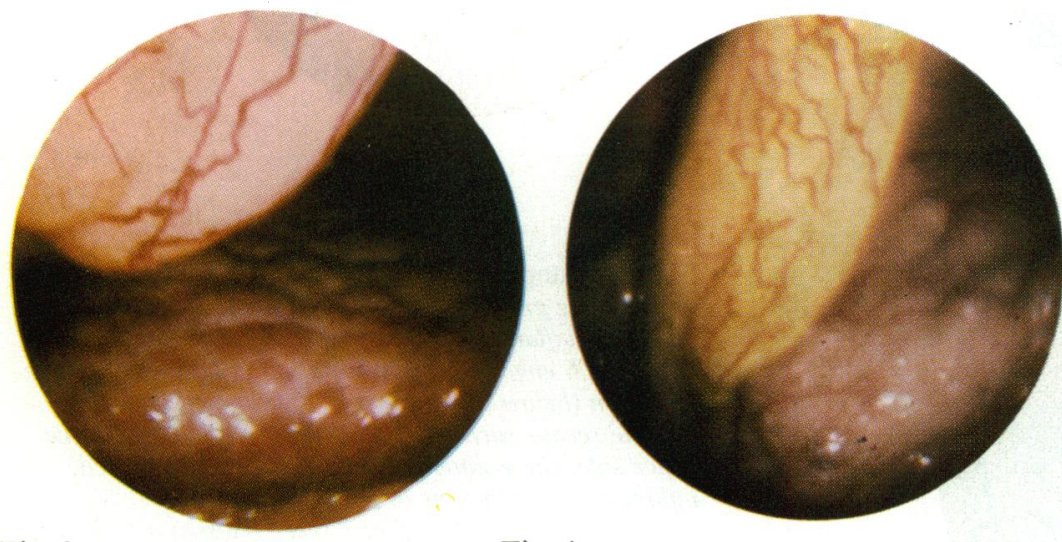

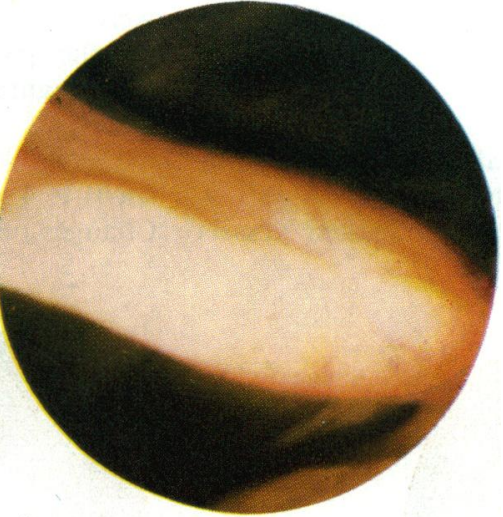

Figs. 1 and 2 Figure 1 shows a teres ligament with apparently normal vascularity and both the hypertrophied lobes of a cirrhotic liver. Figure 2 shows a more detailed view of the delicate vascularity normally exhibited by a teres ligament, below which the fibrotic edge of a small cirrhotic liver (right lobe) is visible.
Figs. 3 and 4 Figure 3 shows increased vascularity of a teres ligament whose serous surface, however, is not inflamed. The coarse nodularity of the liver surface (left lobe) is evident.

Figure 4 shows a more advanced stage of the condition depicted in the preceding figure. Irregular nodularity of the liver surface indicates postnecrotic cirrhosis.
Fig. 3.

Fig. 4.

\begin{tabular}{|c|c|c|c|c|c|c|c|c|}
\hline Patient & $\begin{array}{l}\text { Age } \\
\text { (yr) }\end{array}$ & Sex & Splenomegaly & $\begin{array}{l}\text { Oesophageal } \\
\text { Varices }\end{array}$ & $\begin{array}{l}\text { Superficial } \\
\text { Abdominal } \\
\text { Collateralization }\end{array}$ & Ascites & $\begin{array}{l}\text { Intrahepatic } \\
\text { Pressure } \\
\left(\mathrm{mm} \mathrm{Hg}^{2}\right.\end{array}$ & $\begin{array}{l}\text { Intrasplenic } \\
\text { Pressure } \\
(\mathrm{mm} \boldsymbol{H g})^{2}\end{array}$ \\
\hline
\end{tabular}

Table II Group 2 patients with minimal changes (light vascular engorgement limited to falciform and teres ligaments)

1,2 See footnotes to Table I. 
falciform and teres ligaments (Table II and Figures 3 and 4).

\section{GROUP 3}

Alterations in intraabdominal veins were classified as moderate in 10 patients $(17.5 \%)$. As well as those on ligaments, moderately congested vessels

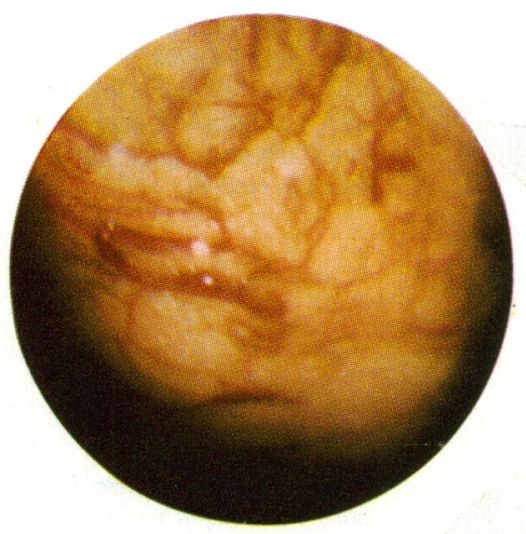

Fig. 5.

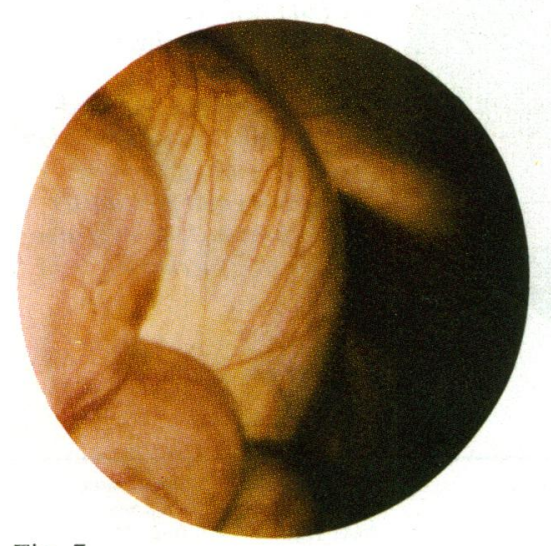

were seen on the greater and lesser omentum, and on the parietal peritoneum, mostly at the subdiaphragmatic surface (Table III and Figures 5, 6, and 7).

\section{GROUP 4}

Changes of the utmost severity in the intraabdom-

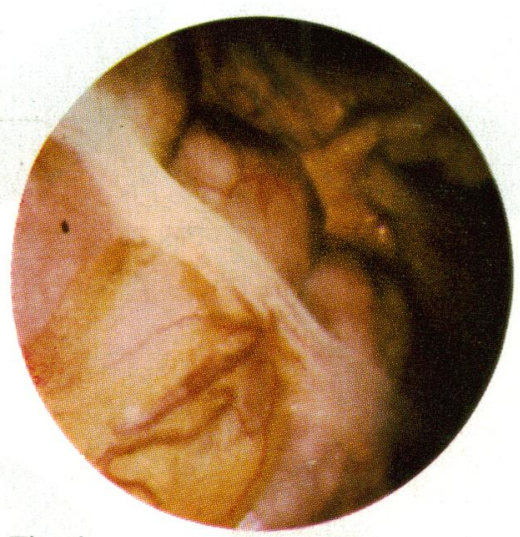

Fig. 6.

Figs. 5, 6, and 7 Figure 5 shows engorged and dilated veins on the greater omentum whose surface is not otherwise inflamed.

In Fig. 6 engorged veins are seen on both the greater omentum (below the readily recognizable taenia coli) and the serous surface of the transverse colon. On the upper side, the greater omentum is shown retracted, inflamed, and adherent to the liver surface.

On the lower half of Fig. 7 three haustra are shown, whose serous vascularity is clearly engorged. Above (centre left) ectasic veins are seen on the gallbladder serous surface and (centre right) the left lobe surface is covered by retracted greater omentum. Also, vascular engorgement is seen on the teres ligament (upper side).

\begin{tabular}{|c|c|c|c|c|c|c|c|c|}
\hline Patient & $\begin{array}{l}\text { Age } \\
(y r)\end{array}$ & $\operatorname{Sex}$ & Splenomegaly' & $\begin{array}{l}\text { Oesophageal } \\
\text { Varices }\end{array}$ & $\begin{array}{l}\text { Superficial } \\
\text { Abdominal } \\
\text { Collateralization }\end{array}$ & Ascites & $\begin{array}{l}\text { Intrahepatic } \\
\text { Pressure } \\
(\mathrm{mm} \mathrm{Hg})\end{array}$ & $\begin{array}{l}\text { Intrasplenic } \\
\text { Pressure } \\
(\mathrm{mm} \mathrm{Hg})^{2}\end{array}$ \\
\hline $\begin{array}{l}\text { C.A. } \\
\text { M.F.P. } \\
\text { E.G. } \\
\text { G'U. } \\
\text { A.S. } \\
\text { D.C. } \\
\text { O.L. } \\
\text { M.P. } \\
\text { D.C. } \\
\text { T.M. }\end{array}$ & $\begin{array}{l}42 \\
47 \\
58 \\
54 \\
61 \\
56 \\
29 \\
37 \\
53 \\
64\end{array}$ & $\begin{array}{l}\mathbf{M} \\
\mathbf{M} \\
\mathbf{F} \\
\mathbf{M} \\
\mathbf{M} \\
\mathbf{M} \\
\mathbf{M} \\
\mathbf{F} \\
\mathbf{F} \\
\mathbf{M}\end{array}$ & $\begin{array}{l}++ \\
- \\
++ \\
++ \\
+ \\
- \\
- \\
++ \\
-\end{array}$ & $\begin{array}{l}\text { Present } \\
\text { Present } \\
\text { Absent } \\
\text { Absent } \\
\text { Present } \\
\text { Present } \\
\text { Present } \\
\text { Absent } \\
\text { Absent } \\
\text { Present }\end{array}$ & $\begin{array}{l}\text { Absent } \\
\text { Present } \\
\text { Absent } \\
\text { Absent } \\
\text { Absent } \\
\text { Absent } \\
\text { Absent } \\
\text { Absent } \\
\text { Absent } \\
\text { Present }\end{array}$ & $\begin{array}{l}\text { Present } \\
\text { Present } \\
\text { Absent } \\
\text { Present } \\
\text { Present } \\
\text { Absent } \\
\text { Absent } \\
\text { Present } \\
\text { Absent } \\
\text { Present }\end{array}$ & $\begin{array}{l}18 \\
19 \\
17 \cdot 5 \\
19 \\
\text { n.d. } \\
\text { n.d. } \\
\text { n.d. } \\
\text { n.d. } \\
20 \\
\text { n.d. }\end{array}$ & $\begin{array}{l}16 \\
21 \\
20 \\
18 \\
\text { n.d. } \\
\text { n.d. } \\
\text { n.d. } \\
\text { n.d. } \\
18 \cdot 5 \\
\text { n.d. }\end{array}$ \\
\hline
\end{tabular}

Table III Group 3 patients, with moderate changes (moderately congested vessels on teres and falciform ligaments, on greater and lesser omentum, and on parietal peritoneum)

${ }_{1,2}$ See footnotes to Table I. 


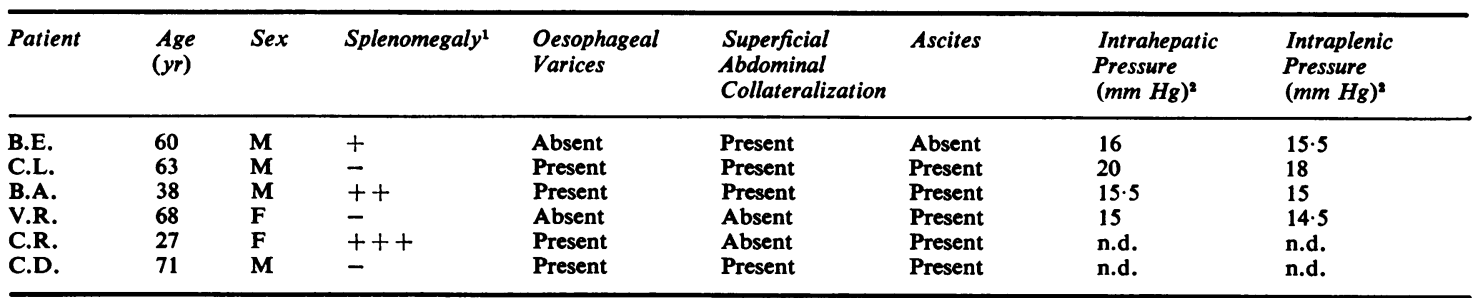

Table IV Group 4 patients with most severe changes (diffuse and conspicuous vascular congestion with haemangiomalike aspects mostly at the teres and falciform ligaments and on diaphragmatic peritoneum)

1,2 See footnotes to Table I.

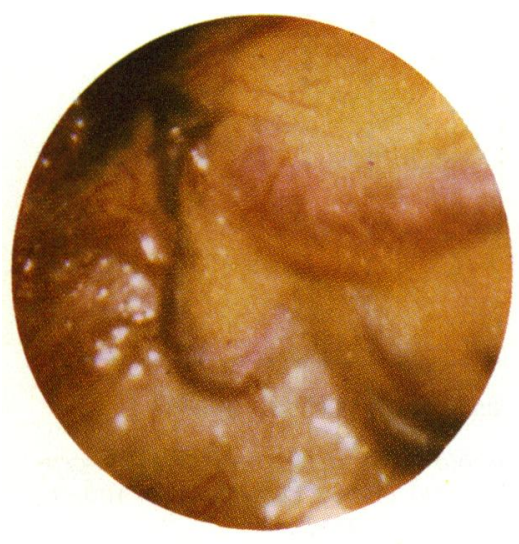

Fig. 8 .

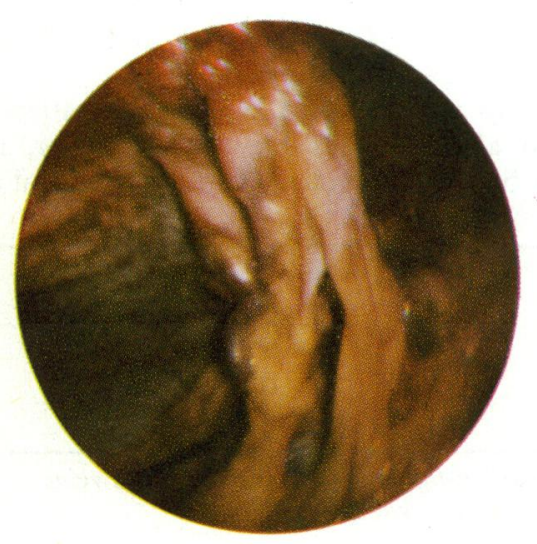

Fig. 10.

inal veins were seen in six patients $(1 \%)$. In these subjects these veins appeared diffusely and conspicuously increased both in number and size, and newly formed channels were seen, occasionally resembling haemangioma (Tables IV and Figures 8,9 , and 10 ).

No significant differences in age and sex distri-

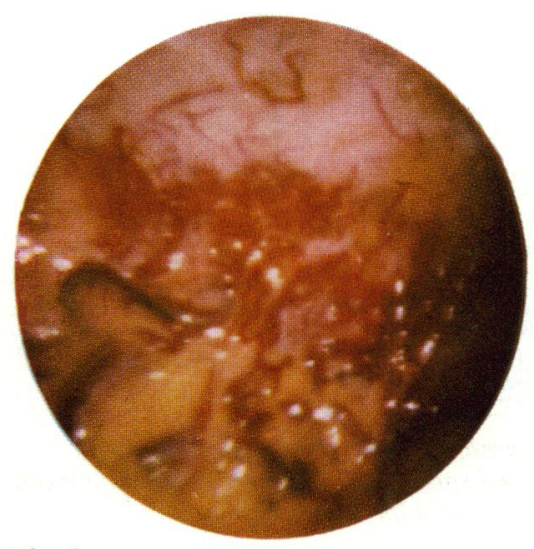

Fig. 9.

Figs. 8, 9, and 10 In Fig. 8 three extremely dilated veins are seen on the greater omentum, their dark bluish colour indicating blood stasis.

Figure 9 (right lower flank). Newly formed vessels, resembling haemangioma, extend from the omental surface to the parietal peritoneum. Again, the colour of greater veins indicates circulatory impairment.

In Fig. 10 partly formed vessels are seen which run on inflammatory adherences between perisplenic tissues and parietal peritoneum; here, extreme degrees of vascularity, inflammation, and circulatory impairment are shown.

bution were found among the groups; clinical conditions seemed to be worse in group 4 than in groups 1,2 , and 3. Liver histology and biochemical findings, however, proved to be overlapping among the four groups. No important relationship was found between splenomegaly and serum globulins (Fig. 11), and, respectively, between ascites and serum 


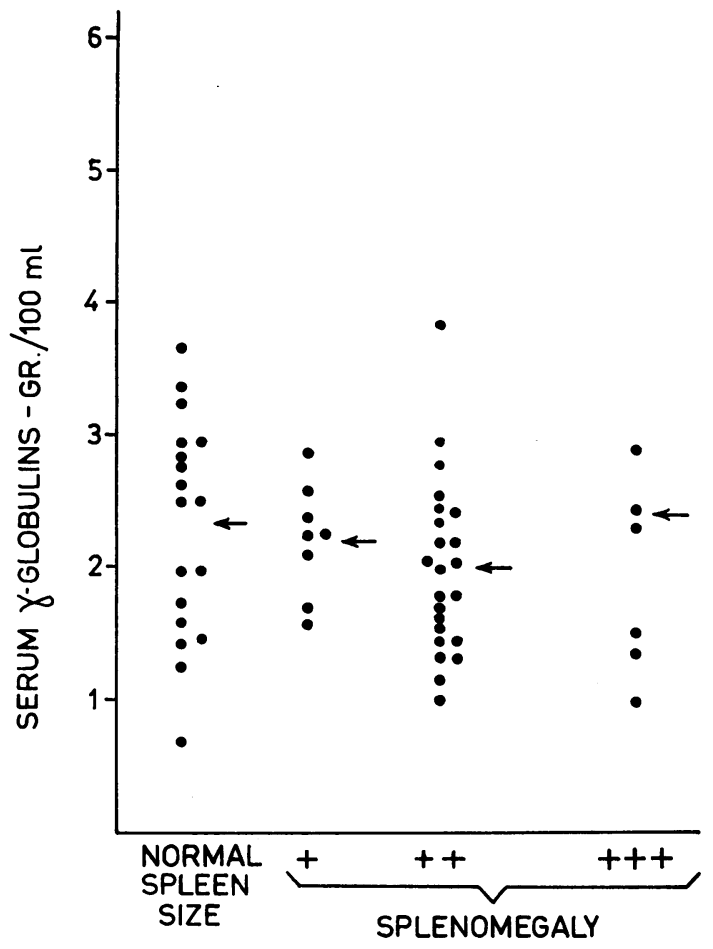

Fig. 11 Relationship between serum $\gamma$-globulin concentrations and spleen size. The arrows indicate mean values for serum $\gamma$-globulin concentrations.

albumins (Fig. 12). As shown in Tables I-IV, abnormally raised intrahepatic and intrasplenic pressures were recorded in patients belonging to all four groups; the lower values, however, were found in group 4.

As shown in Table V, no relationship could be found between changes in intraabdominal veins and, respectively, abdominal wall collateralization and oesophageal varices. Superficial venous dilatation and radiological evidence of varices were frequently lacking in patients with altered intraabdominal veins, whereas these features were readily apparent in some patients with normal

\begin{tabular}{lcll}
\hline Group & No. of Patients & $\begin{array}{l}\text { No. of Patients } \\
\text { with Abdominal } \\
\text { Wall Collaterals }\end{array}$ & $\begin{array}{l}\text { No. of Patients } \\
\text { with Oesophageal } \\
\text { Varices }\end{array}$ \\
\hline 1 & 25 & $4(16 \%)$ & $3(12 \%)$ \\
2 & 16 & $1(6 \%)$ & $2(12 \%)$ \\
3 & 10 & $2(20 \%)$ & $5(50 \%)$ \\
4 & 6 & $4(66 \%)$ & $4(66 \%)$ \\
\hline
\end{tabular}

Table V Relationship between intraabdominal veins seen on peritoneoscopy and abdominal wall collateralization oesophageal varices

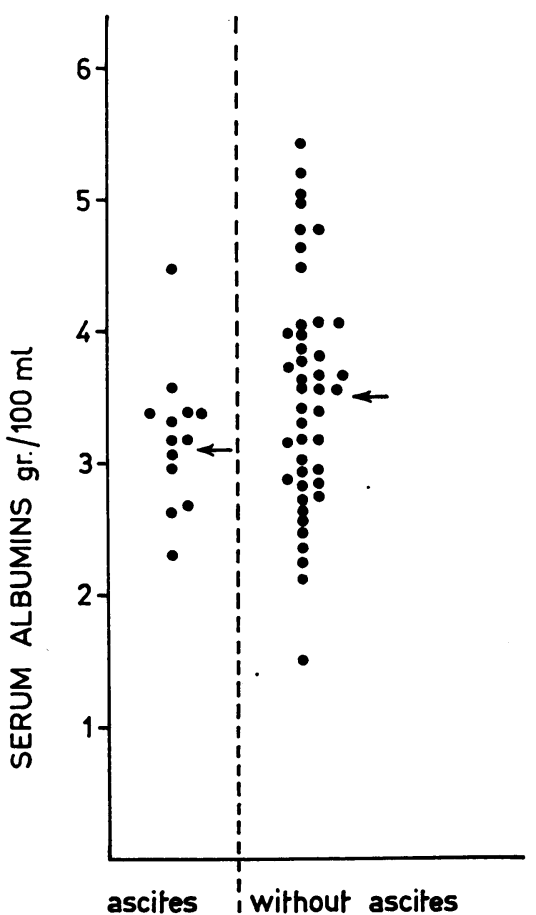

Fig. 12 Relationship between serum albumin concentrations and ascites. The arrows indicate mean values for serum albumin concentrations.

veins. Either of them, moreover, was isolatedly present in a number of patients with and without involvement of the intraabdominal veins.

Splenomegaly was felt in a number of patients belonging to all groups (Table VI). However, it appeared to be more frequent (Table VI) and of a

\begin{tabular}{lll}
\hline Group & No. of Patients & $\begin{array}{l}\text { No. of Patients } \\
\text { with Splenomegaly }\end{array}$ \\
\hline 1 & 25 & $17(80 \%)$ \\
2 & 16 & $13(75 \%)$ \\
3 & 10 & $5(50 \%)$ \\
4 & 6 & $3(50 \%)$ \\
\hline
\end{tabular}

Table VI Relationship between intraabdominal veins seen at peritoneoscopy and splenomegaly

higher degree (Table I-IV) in patients with normal rather than in those with altered intraabdominal veins.

Ascites (Table VII) was never found in patients with normal veins, neither had it been recorded in their past clinical story. A few hundred millilitres of clear fluid, not detectable by physical examination, were demonstrated by peritoneoscopy in only 


\begin{tabular}{lll}
\hline Group & No. of Patients & $\begin{array}{l}\text { No. of Patients } \\
\text { with Ascites }\end{array}$ \\
\hline 1 & 25 & None \\
2 & 16 & $1(6 \%)$ \\
3 & 10 & $6(60 \%)$ \\
4 & 6 & $6(100 \%)$ \\
\hline
\end{tabular}

Table VII Relationship between intraabdominal veins seen at peritoneoscopy and ascites

one out of the 16 patients with minimal changes in intraabdominal veins belonging to group 2 . In the remaining two groups, with moderate and marked alterations in intraabdominal veins, the frequency of ascites rose to $60 \%$ and $100 \%$ of the patients.

Percutaneous splenoportography was carried out in 16 patients; five belonged to group 1, four to group 2, four to group 3, and three to group 4. As shown in Table VIII, venographic appearances did not in every case correlate with peritoneoscopic features, for abnormal venograms could be demonstrated in patients with normal intraabdominal veins and vice versa.

\begin{tabular}{llll}
\hline Group & No. of Patients & $\begin{array}{l}\text { No. of Patients } \\
\text { with Normal } \\
\text { Splenoportogram }\end{array}$ & $\begin{array}{l}\text { No. of Patients } \\
\text { with Abnormal } \\
\text { Splenoportogram }\end{array}$ \\
\hline 1 & 5 & 2 & 3 \\
2 & 4 & 2 & 2 \\
3 & 4 & 0 & 4 \\
4 & 3 & 1 & 2 \\
\hline
\end{tabular}

Table VIII Relationship between intraabdominal veins seen at peritoneoscopy and on splenoportograms

Abnormal splenic portograms showed features usually found in liver cirrhosis, ie, distortion of the intrahepatic vasculogram phase and/or diversion of portal blood away from the liver to the systemic circulation, mostly by short gastric-gastroesophageal azygous and inferior mesenteric collateral venous systems.

\section{Discussion}

The share of intraabdominal vessels disclosed by peritoneoscopy is indicative of liver cirrhosis in a much more distinctive and independent manner than the other portal vein tributaries. In fact, this study does not show any definite relationship between these and intraabdominal veins.

Superficial collateralization and oesophageal varices, although prevailing among patients with altered intraabdominal veins, could as well be demonstrated in a number of patients in whom these veins appeared strictly normal. Moreover, 1A abnormal venograms were obtained in three patients with normal intraabdominal veins, thus confirming the suggestion that in cirrhotics the portal venous tributaries may be variously affected in different anatomical areas (Solmi and Righi Riva, 1968).

Splenomegaly was more frequent in patients with normal or slightly altered intraabdominal veins than in those with major disorders, and the largest spleens belonged almost exclusively to patients with normal intraabdominal veins. These findings suggest that endoabdominal collateralization and spleen enlargement may bear an inverse relationship with each other, and be of some value in understanding the reason(s) why the size of the spleen does not correspond directly to the degree of portal hypertension, as pointed out by other authors (Panke, Moreno, and Rousselot, 1960; Shaldon, 1962; Patrassi, Dalpalu, and Rual, 1961). In the present study within certain limits splenomegaly and collateralization of intraabdominal veins seem to be alternative phenomena. It should be considered, however, that several factors can act to reduce or inhibit the effects of portal hypertension on the splenic vascular bed, such as the amount of splenic fibrous tissue and the occurrence of splenic infarction. In addition, causes other than portal hypertension have been advocated in explaining splenomegaly in cirrhotics (Popper and Zak, 1958), thus making this point worth further evaluation.

Intrahepatic and intrasplenic pressure measurements proved to be abnormal in all patients submitted to these procedures, even those with major involvement of the intraabdominal veins. These findings confirm that naturally established shunts rarely seem to alleviate portal hypertension completely (Rousselot, Moreno, and Panke, 1959). They diverge, however, from those of Rousselot et al (1959) in that in the present study the greatest changes in intraabdominal veins were associated with the lowest abnormal values for portal pressure. This finding, indeed, is in keeping with Hunt's apparently paradoxical statement that portal hypertension decreases as cirrhosis advances (Leger, 1966).

Recognizable alterations in intraabdominal veins were always observed in patients with ascites, whereas peritoneal effusion was never found in patients with normal veins. Whatever the ultimate cause(s) of ascites might be, from this remarkable constancy in findings it appears that alterations in intraabdominal veins should at least be regarded as permissive factors for the development of ascites. Moreover, these observations support the possibility that the peritoneal capillary membrane can play an active role in controlling the passage of fluid, as recently stated by Sherlock (1968). 
Conclusively, peritoneoscopy'is an additional source of information in studying the circulatory disorders caused by cirrhosis of the liver. The vascular section disclosed by peritoneoscopy is relatively independent from those explored respectively by physical examination, barium swallow, and splenoportography. Recognizable alterations in this particular section are invariably disclosed by peritoneoscopy in ascitic patients, thus suggesting some pathogenetic role for these diseased vessels in producing ascites. It is well known that ascites worsens the prognosis of liver cirrhosis (Schiff, 1969). Peritoneoscopic evaluation of the intraabdominal veins may therefore be of some prognostic value in assessing the successive clinical course of cirrhotic patients. We are at present evaluating long-term data which suggest a correlation between refractoriness of ascites and the severity of changes in the intraabdominal veins.

\section{References}

Atkinson, M., and Sherlock, S. (1954). Intrasplenic pressure as index of portal venous pressure. Lancet, 1, 1325-1327.

Beck, K., Dischler, W., Helms, N., Kiani, B., Sickinger, K., and Tenner, R. (1968). Atlas der Laparoskopie, pp. 146-151. Schattaner, Stuttgart and New York.
Leger, L. H. (1966). Splenoportography, p. '56. Thomas, Springfield, Illinois.

Orrego-Matte, H., Amenabar, E., Lara, G., Baraona, E., Palma, R., and Massad, F. (1964). Measurement of intrahepatic pressure as index of portal pressure. Amer. J. Med. Sci., 247, 278-282.

Palmer, E. D., and Boyce, H. W. Jr. (1964). Manual of Gastrointestinal Endoscopy, pp. 88-100. Williams and Wilkins, Baltimore.

Panke, W. F., Moreno, A. H., and Rousselot, L. M. (1960). The diagnostic study of the portal venous system. Med. Clin. N. Amer., 44, 727-742.

Patrassi, G., Dalpalu, C., and Rual, A. (1961). La pletora portale. Atti Congr. Soc. ital. Med. intern., 62, 506.

Popper, H., and Zak, F. G. (1958). Pathologic aspects of cirrhosis. Amer. J. Med., 24, 593-619.

Rousselot, L. M., Moreno, A. H., and Panke, W. F. (1959). Studies on portal hypertension. IV. The clinical and physiopathologic significance of self-established (nonsurgical) portal systemic venous shunts. Ann. Surg., 150, 384-412.

Solmi, G., and Righi Riva, G. C. (1968). L'esame laparoscopico nei circoli collaterali dell'ipertensione portale. Gazz. Sanit., $39,61-62$.

Schiff, L. (1969). Disease of the liver, 2nd ed., p. 355. Lippincott, Philadelphia.

Shaldon, C. (1962). Dynamic aspects of portal hypertension. Ann. roy. Coll. Surg. Engl., 31, 308-329.

Sherlock, S. (1968). Diseases of the Liver and Biliary System, 4th ed., p. 138. Blackwell, Oxford.

Siede, W., and Schneider, H. (1962). Leitfaden und Atlas der Laparoskopie, pp. 34-50. Lehmann, München.

Steiner, R. E., Sherlock, S., and Turner, M. D. (1957). Percutaneous splenic portal venography. J. Fac. Radiol. (Lond.), 8, 158-177.

Williams, R. (1967). The investigation of a patient with portal hypertension. In The Liver, edited by A. E. Read, pp. 253-262. Butterworths, London.

Wittman, I. (1966). Peritoneoscopy, vol. 1, pp. 118-120. Akadémiai Kiadó, Budapest. 